\author{
Kazimierz Piotrowski \\ - https://orcid.org/0000-0002-8693-2233 \\ Strzemiński Academy of Art in Łódź \\ kazimierz.piotrowski@neostrada.pl
}

\title{
SOME CONTEXTS OF THE QUESTION ABOUT ART From Essentialism to Machine Epistemology
}

\begin{abstract}
Since I know the client in Amsterdam I have a dream to visit the Van Gogh Museum. See his originals and to feel how he felt. I want to get some inspiration from his paintings then my goal will be more clear," read the subtitles in the movie China's Van Goghs (2016). It is difficult for us to understand what the mass replicas manufacturer means. Does he want to deepen the knowledge of the knowing that type or does he simply want to increase the effectiveness of the knowledge of the knowing how type? But why would Zhao Xiaoyong - who has increasingly better Chinese connectivity - bother, despite the objections voiced by his wife, who is in charge of their home budget, since there is no guarantee that his thriving business will provide better art effects than Van Gogh originals? Are there other contexts - as, for example, Unsupervised Learning - in which we can look differently at Gilbert Ryle's famous distinction and privileged position of well-established knowledge?
\end{abstract}

Keywords: art, essentialism, extensionalism, intensionalism, non-monotonic logic, machine epistemology, unsupervised learning.

I think artist, painter, painter-worker these are just labels.

China's Van Goghs (2016)1

The question Is a conceptualizing of 'art' needed? problematizes the natural - let us say commonsensical, practical or realistic - attitude of a man who, along with the mastering the rules of language, formulates the question: What is this?

1 China's Van Goghs (2016), a film by Yu Haibo and Kiki Tianqi Yu, 40'16, https://www. dailymotion.com/video/x6fcef2 (09.10.2019). 
pointing to a specific thing. Having its name, we ask e.g. What is a hamburger? And by obtaining appropriate knowledge about the purpose, ingredients, recipe, final appearance and taste of this American fast food, we are able to prepare it ourselves or recognize and order it almost in every corner of the globe, asking for local flavor additives. According to such colloquial understanding, today the concept of art - just like Chinese cuisine, for example - belongs to the concepts of globalizing common sense. Are there contexts in which we can give up the well-established knowledge acquired as a result of the centuries-old reflection and the development of theory?

The concept of the boas artes discovered by Westerners in the 16th century, ${ }^{2}$ and in the 20th century anti-art or opera aperta, to cite the 1962 semiological concept proposed by Umberto Eco, ${ }^{3}$ who had confronted Western aesthetics with Indian aesthetics several years earlier ${ }^{4}$, have become - like the Euro-American technology - the property of the culture of Japan, China, India, and even of the modernizing world of Islam. Today we watch the Louvre collection in Abu Zabi and this disseminating process of the concept of fine arts will not be stopped by the destruction of the Buddha statue in Afghanistan or the Baalshamin temple in Palmyra. If the Western world prevailed, overcoming the rise of iconoclasm, why should the Middle East not cope with the phobias of the Taliban or Daesh? However, can we expect assimilation of the entire spiritual heritage of Western art philosophy by Arab connoisseurs of the Louvre masterpieces, since we ourselves have a problem with accepting political implications of the Quran or are suspicious of Chinese medicine? If art is interpreted in many ways because the work of art itself - open, according to Eco - is not clearly defined, then on what epistemological basis does the expression art function, for example, in Google Translate? And what is the results of this?

Are there contexts in which we can look differently at Gilbert Ryle's famous distinction? ${ }^{5}$ Because we must always examine art only in the hierarchical order of episteme, defined by the opposition knowing that / knowing how? No wonder that today we formulate a question about the sense of further defining the concept of art as a certain type of rationality, fine arts, bohemia or avant-garde etc. Our problem goes beyond the problem of the auratic art, which was once examined in depth by Walter Benjamin, or the dilemma of avant-garde or

2 W. Tatarkiewicz, Dzieje sześciu pojęć. Sztuka, piękno, forma, twórczość, odtwórczość, przeżycie estetyczne, Państwowe Wydawnictwo Naukowe, Warszawa 1988, pp. 30-34.

3 U. Eco, The Open Work, transl. by A. Cancogni with an introduction by D. Robey, Harvard University Press, Cambridge, Massachusets 1989.

4 Idem, Estetyka indyjska a estetyka zachodnia (Problemi di estetíca indiana, 1958), in: idem, Sztuka, transl. M. Salwa, Wydawnictwo M, Kraków 2008, pp. 64-80.

5 G. Ryle, Knowing How and Knowing That, "Proceedings of the Aristotelian Society" 1946, vol. 46 (1945-1946), pp. 1-16, https://plato.stanford.edu/entries/ryle/ (09.10.2019). 
kitsch analyzed by Clemente Greenberg, who considered the issue of Alexandrianism in the face of the totalitarian deviation of populist taste. The process of globalization caused the fact that the tensions between the knowing that and the knowing how have increased dramatically, and within the theoretical knowledge about art between essentialism and anti-essentialism, between the analogous, unambiguous, polysemous or purely instrumental understanding of art, between art as a knowledge system based on specialized education and learning art without supervision.

To answer the above-mentioned question, we must consider it in several epistemic contexts. To show them, one must first distinguish between levels of episteme, in which concepts have three functions: 1. basic, 2. factorial, and 3. result. The first level sets out the linguistic rules of sense (the correctness of expressions shape within various dictionaries that - through the regulative assumption of the common meaning of these expressions - make the word art translatable into other languages); the second level includes the rules for transforming these expressions within a grammar or program (art as genres or techniques, styles, manners, specific actions, procedures, methods of application, etc.); on the third level - if we can distinguish activity from product - we have a final result of transformation (art as something created as a deliberate good - useful or enjoyable one, having a desired value: drawing, painting, sculpture, building, poem, concept, song, symphony, photography, film, ready-made, happening, action, performance or self-creation, and even the entire institutional Art World). Asking, whether we need the definition of art today, we assume the ability to opt out of one of the distinguished functions of art use.

This question about the possibility of eliminating some function has the following epistemic contexts: 1. essentialist, 2. semi-essentialist, 3. anti-essentialist, 4. extensionalistic, 5. monotonic, 6. intensionalistic, 7. non-monotonic, and 8. machine-epistemological one. We are primarily interested in the inferential relationship between these contexts and conclusion. We show that contexts 1-5 have iunctim that differs from iunctim contexts 6-7, which implies that the traditional epistema (1-5) is complemented by machine epistemology in the context 8 , where concept of art ceases to be a basic, factorial or result term determined only by man, but it begins to define itself as the so-called artificial intelligence with the effect of Augmented Intelligence, the development of which increases uncertainty and risk.

\section{The essentialist context}

The essentialist context assumes the primary order of the commonsensical dictionary and defines the necessary function of the basic concept of art. The 
mentioned hamburger, invented by Fletcher Davis in 1904, like Google Translate launched in 2006, are neither basic nor factorial concepts - like cooking or statistical browsing the big data in the Internet, but only result concepts. We know that there were very poor common sense variations. The Aborigines did not know many basic arts of this kind, such as pottery, weaving or animal husbandry, although they hunted and used boomerang, didgeridoo, and made rock paintings, so they owned some art. The dictionary of the globalizing common sense - a context composed of expressions of different languages driven by hardware and software of artificial intelligence - covers a range of art concepts also the famous and groundbreaking concept of fine arts as a special ability to craft objects designed to fulfil specific spiritual needs, which was introduced by Charles Batteux ${ }^{6}$. Were these needs known to Aborigines or will they be met by some intelligent organisms living over the next millennia on our planet, since these needs were only determined as a result of the museumization process from the second half of the 17th century, when in 1661, the Öffentliche Kunstsammlung in Basel was made available for the first time to the public. ${ }^{7}$ However, the essentialist approach abstracts from the historical development of functions and preferences within the common sense dictionary and its changing contexts. Essentialism claims that art is a basic concept that encompasses other - factorial and result - concepts of art. There are grounds for wondering whether the fine arts concept should be included in the scope of basic or factorial terms, but according to essentialists it does not change the fact that art word has its essence, so it has a significant definition which determines the concepts derived from it, such as a museum institution providing a proper framing, the health of the artworks and a level of comfort for viewers in the decontexstualized public space specially adapted to this quasi-sacral display of art and theory of its disinterest perception initiated by the neo-Platonic philosophy of Anthony Ashley Cooper, Third Earl of Shaftesbury. ${ }^{8}$

These isolationist endeavors of essentialism, reinforced by 19th-century aestheticism (art for art sake) and formalism, have established the project of a separate research discipline proposed by Max Dessoir and called the general art science (Allgemeine Kunstwissenschaft). ${ }^{9}$ At the beginning of the 20 th century, the thought on art was directed by Dessoir's program - also undertaken by

6 Ch. Batteux, Les Beaux-Arts réduits à un même principe (1746), ed. J.-R. Mantion, Aux Amateurs de livres, Paris 1989; see: W. Tatarkiewicz, Dzieje sześciu pojęć, op. cit., pp. 31-34.

7 D. E. W. Fenner, Art in Context: Understanding Aesthetic Value, Athens, Swallow Press - Ohio University Press, Ohio 2008, pp. 2-3.

8 Ibidem, pp. 4-5, 9.

9 M. Dessoir, Aesthetik und allgemeine Kunstwissenschaft, Verlag von Ferdinand Enke, Stuttgart 1906, https://archive.org/details/sthetikundallge00dessgoog/page/n7 (09.10.2019). 
Emil Utitz and other researchers (in Poland by Stanisław Ossowski and Mieczysław Wallis seeking a way to overcome relativism in the aesthetic evaluation theory) - which was dominated by a reorientation towards systematic knowledge. This change took place due to the anti-positivist breakthrough, the moving away in methodology from the pointless inductive logic (e.g. Gustav Theodor Fechner) to the holistic approaches. Two essential, expansively developing currents - psychoesthetics and formalism (the so-called reines Sehen trend), opposing or sometimes agreed (e.g. Eduard Hanslick, Benedetto Croce, Wilhelm Worringer and others) - have prepared a sufficient basis for an attempt to the complemental (subjective and objective) view of art. Dessoir assumed that the subject of general art science is admittedly polymorphous but it is unified. The goal of art science should be to capture the extensive fact of art in all its relations. The ambition of the Kunstwissenschaft was to work out the foundations for research from various positions: by artists, critics, sociologists, ethnologists, psychologists, historians, and philosophers. This resulted in the postulate that system and method of the general art science should be independent of historical research. It is possible thanks to the phenomenological overcoming of the difference between induction and deduction in the eidetic description. Utitz preferred especially phenomenological strengthening the Kunstwissenschaft (while Dessoir mentioned descriptive psychology in the spirit of Franz Brentano). Quoting Edmund Husserl that science does not know the concept of a deep sense Utitz believed that art is completely available for rational research and phenomenology can be a method that will guarantee the theses of art science a general importance. ${ }^{10}$

\section{The semi-essentialistic context}

To determine how we can differently understand the basic function of the art concept, let's refer to the so-called privative theory of art founded on philosophical realism (neo-Thomism). ${ }^{11}$ This theory - also claiming universality and neutrality, and therefore applicable in all possible cases - differs from essentialism of evidentialist type (Platonism, phenomenology, Kunstwissenschaft). It can be described as a semi-essentialism. This is because it is aware of the error of essentialism and avoids investigations that make the basic concept of art unambiguous (as well privative theory criticizes the ambiguity of antiessentialism). Therefore, it was fundamentally based on the theory of analogy

10 E. Utitz, Grundlegung des allgemeinen Kunstwissenschaft, Verlag von Ferdinand Enke, Stuttgart 1914, https://archive.org/details/grundlegungdera00utitgoog/page/n7 (09.10.2019).

11 H. Kiereś, (2006) Człowiek i sztuka. Antropologiczne watki problemu sztuki, Polskie Towarzystwo Tomasza z Akwinu, Lublin 2006. 
and - according to Aristotelian-Thomist tradition - on moderate realism. The privative theory recognizes the concept of art in the metaphysical context of being analogy and considers this notion - in which it does not differ from essentialism - as inalienable for all articulations of common sense. Also when the concept of art does not yet exist explicitly in it. The privative theory assumes that a source of art is the human experience of depriving of something (in Latin privatio). People have have the ability to complement or compensate this - analogously understood - lack by their inventiveness in the physical and spiritual sphere (in Greek techne, poiesis, in Latin ars, factibile), therefore genus humanum arte et ratione vivat. ${ }^{12}$ The lack is constantly supplemented by the natural ability of human reason (nous poietikos, recta ratio factibilium) to create what is necessary, possible or probable. The privative conception assumes analogical approach to the essence of art not only as a factorial or result notion, but above all as the basic potency (dýnamis, potentia), whose raison d'etre as a rational and permanent disposition (hexis, dispositio, habitus) is the tension in the nature caused by the experience of analogously understood lack and the need its purposeful, rational, conscious, eudaimonistic complementation. At every level of episteme, in every manipulation of the concept of art, we must understand it analogously, and not explicitly like essentialists. They want to derive from the essential definition of art a priori criteria for its valuation, but these must also be understood analogously as, for example, beauty. In every possibility of art and its actualization in a form (logos) of human work, one can see this fundamental tension between what is and what is lacking in our nature or what remains in potency and what must be artificially supplemented or actualized by analogously understood imitation of the nature in the work (mimesis). However, the ambiguously understood lack as a non-being in the human nature will never be completely compensated by the artificial world created by man by his natural forces. The upshot is that the privative art theory points to a religious perspective.

\section{The anti-essentialist context}

Anti-essentialists claim that the question about the essence of art does not make sense, ${ }^{13}$ because the essential definition of art is logically precluded. ${ }^{14}$

12 Ibidem, pp. 24-40.

13 L. Chwistek, Nowa poezja polska (I. Uwagi metodologiczne), "Nowa Sztuka” 1922, no 2, pp. 11-13, http://bluemountain.princeton.edu/bluemtn/?a=d\&d=bmtnabm192202-01.2.15\& (09.10.2019); idem, Zagadnienie metody w estetyce, in: idem, Zagadnienia kultury duchowej w Polsce, Księgarnia Gebetnera i Wolffa, Warszawa 1933, pp. 249-277.

14 H. Kiereś, Sztuka, op. cit., p. 34. 
One should reject the essentialist fallacy of the tradition of theoretical reflection on art. One can only ask how someone constructs concept of art, how uses or mentions the expression art, and then correlate all answers. Anti-essentialism - inspired by the development of the axiomatic method of formal sciences (logistics) and in the version of analytical philosophy ${ }^{15}$ - focuses on the factorial and result concepts of art when art is functioning expressis verbis. According to aposterorism of anti-essentialism, the concept of art is open, fluid and controversial (parennially debatable), because its changing scope and content are determined by different motives, not by one cause. That is why the concept of art is expressed in various axioms (propositional functions) of an empiricaldeductive theory or its meaning are different ways of using the expression art on basis of specific grammars, but the point here is that criteria to determine and value art derived from them are neither necessary nor sufficient. What's more, the lack of a basic art concept (the essence of art) as logically excluded is understood here as a condition for effective functioning the factor and result concepts of art or anti-art, which is understood voluntarily. Anti-essentialists argue that the use of the basic and unequivocally understood notion essence of art results in the creation of a reducing or normative theory (e.g. aesthetic one), which blocks the development of artistic creativity or a game of art. This argument is consistent with Ludwig Wittgenstein's paradigmatic anti-essentialism investigating the concept of time. Trying to understand the essence of time, we encounter unmanageable difficulties that disappear when we use the expression time. Anti-essentialists do the same in their analytical and therapeutic aesthetics, which exposes dogmatism and fundamentalism of essentialism to settle for what people accept as art.

Despite these contradictions, there is a certain iunctim between essentialism and anti-essentialism. The first is already visible in the name itself. It may be trivial to say that verbally, psychologically and logically anti-essentialism must assume the concept of essentialism which it attempts to negate. We also see that both semi-essentialism and anti-essentialism presuppose the concept of depriving of something (privatio). Privative semi-essentialism says that the source of art is lack, what anti-essentialism does not directly deny, allowing in its relativism and such - one of the possible - conception of art. Thus, by denying the privative art conception as a basic concept, it shifts this concept to another episteme level as a purely factorial or result concept. What's more, as we saw earlier, anti-essentialism makes this act of giving up the need to define the concept of art its raison d'etre. Therefore, in anti-essentialism there is a recupe-

15 Idem, Anglosaska estetyka analityczna, in: A. B. Stępień, Propedeutyka estetyki, Towarzystwo Naukowe Katolickiego Uniwersytetu Lubelskiego, Lublin 1986, pp. 143-171. 
ration of privative semi-essentialism, i.e. the negating repetition of the concept or intention of the privative art theory. It means that the concept of lack is no longer understood fundamentally - metaphysically or anthropologically - as the existence reason of the underlying concept of art, but only factorically (instrumentally). It is not the experience of lack that is the sole source of art, but the experience of the essence absence in the art is a condition for its effective functioning.

\section{The extensionalist context}

There is another iunctim between essentialism and anti-essentialism that can be explained when we consider the possibility of extensionalist interpretation these positions. ${ }^{16}$ Let essentialism and anti-essentialism be propositional functions that are supposed to give the same result concept of art:

Essentialism: to get result concept of art, add 1 to art and multiply by 2 . Anti-essentialism: to get result concept of art, first multiply art by 2 and add 2 .

To some extent, essentialism and anti-essentialism, although intensional different, can give the same result concepts of art, and therefore these functions are extensionally equal. Here is an example: for an essentialist and antiessentialist a portrait can be the same result concept of art that satisfies their cognitive, emotional and aesthetic needs. But the essentialist achieves this effect by using a traditional hand drawing, while the anti-essentialist - using the same paper and pencil - receives support from a robot. An experiment will be conducted that shows that essentialist and an anti-essentialist are unable to distinguish between the two drawings. The difference will not be seen with the naked eye. We can express this extensionalist context in sentence functions using the symbols in the Polish notation: $e$ (essentialism), $N e$ (anti-essentialism) and $p$ (portrait). As we saw earlier, we have a result in the form of the following statements: 1. Cep, 2. CNep, 3. CACepCNepp. This extensionalist interpretation of the dispute between essentialism and anti-essentialism shows that there are some result notions of art, the recognition of which does not necessarily involve the dispute settlement between these positions.

16 W. Marciszewski (Ed.), Logika formalna. Zarys encyklopedyczny z zastosowaniem do informatyki i lingwistyki, Państwowe Wydawncitwo Naukowe, Warszawa 1987, pp. 14-15, 289. 


\section{The monotonic context}

The theorem CACepCNepp reveals the third iunctim between essentialism and anti-essentialism. As it clearly arises from the sentence both theories form a monotonic context. The principle of monotonicity was formulated - earlier assumed by logicians implicitly - among others by Alfred Tarski in his treatise Über einige fundamentale Begriffe der Metamathematik (1930). It claims that if a conclusion is a logical consequence of a set of premises, then it is also a consequence of any of their wider set, thus an extension of a set of premises allows to accept at least these conclusions which were inferred from the original set. If we accept that the claim a portrait is art is a logical consequence of the set of premises of the essentialist theory, then an extension of this set of premises to the premises of anti-essentialism allows us to recognize the conclusion derived from the original set, i.e. that a portrait is art. Let us note that any premises may be attached, and therefore also premises contrary to the premises of the original set, i.e. essentialism.

This is how many aestheticians understood and still understand theory of art. They organize a knowledge of art on the basis of the expressed above concept of a cumulative set, which may be freely extended: 1 . by adding successive premises in the form of works of art to the established core of (theory of) art, whose findings will remain valid even when in a purely formal logical way we add any premises contradictory to the original premises and conclusions; 2 . by enriching for example Władysław Tatarkiewicz's alternative definition of art with successive ars modi. ${ }^{17}$ In terms of logic, there is no significant difference here, whether we think about an essentialist (metaphysical or phenomenological, eidetic etc.) insight into the nature of art or about inductive generalization of the data of the experience and extrapolation of results, or when we talk about negating the existence of such essence or core (anti-essentialism, like Leon Chwistek, ${ }^{18}$ Moritz Weitz in his Philosophy of the Arts (1950) and others ${ }^{19}$ ) and stopping only at accumulating knowledge about what people of dissimilar individual views consider to be art. In the first case the accumulation of knowledge aims to sanction the existence of essence of art, in the other it serves to prove that such an essence does not exist due to the existence of contradictory views of art, whose validity we recognize on the ground of relativism. The investigations of essentialists and anti-essentialists, although they lead to contradictory

17 W. Tatarkiewicz, Dzieje szęściu pojęć, op. cit., pp. 48-52.

18 See K. Piotrowski, Antyunizm Leona Chwistka - o defensywnej fazie awangardy lat trzydziestych, "Artium Questiones” 2004, no. 15, pp. 30-37.

19 H. Kiereś, Sztuka, op. cit., p. 35-38. 
results as to the existence of the basic concept of art essence, are based on the same logic - monotonic one.

An example of a monotonic approach to art, however an anti-essentialist theory, is the conceptualism of the Art and Language group, which uses Donald Judd's nominative definition of art: if an artist calls something art, then it is art. But conceptualists corrected as a categorical mistake the identification of art with the name as a subject in the sentence art exist or art is ..., proposing the format of art, i.e. that something becomes art as a result of extending the set of premises and conclusions generated and supplemented by the art community. ${ }^{20}$ Joseph Kosuth expressed this monotonic approach in the form of tautological model of art (Art as idea as idea) in his famous essays Art after Philosopy (1969). ${ }^{21}$ Works of art have been compared to analytical sentences whose non-synthetic meaning is determined by the autonomous context of selfdefining art. According to Wittgenstein's non-denotative concept, the meaning of art is a using way the expression art.

\section{The intensionalist context}

Some logical convergence can be found between different theories. For example, the essentialist concepts of Charles Batteux, Georg Wilhelm Friedrich Hegel, Stanisław Ignacy Witkiewicz, Władysław Strzemiński or Joseph Kosuth belong to the extensionalist context of art, because they assume that the use of basic or factorial concepts of art always gives the same result: art work as beauty (Batteux), as an expression of the substantial originality of the Spirit in a sensual form (Hegel), as an experience of the Pure Form (Witkacy), as an unity with the inherent data of the artistic genres (the so-called unism of Strzemiński) or as an analytical sentence - a tautology (Kosuth), regardless of which variables an artist uses. The concept of art - in itself unchanging as the basic concept - is therefore extensible at the episteme level defined by factorial and result concepts. Similarly, in anti-essentialism, which is a meta-object approach to the extensionalist understanding of art. This is a relativist approach, i.e. every proposal to recognize something as art is relatively important, because it enriches our inconclusive knowledge about art. Thus, in anti-essentialism

20 See:K. Piotrowski, The Linguistic Turn in ConceptualismandAfter, “Art Inquiry” 2015, no. 17,pp. 145-166, http://cejsh.icm.edu.pl/cejsh/element/bwmeta1.element.desklight-9a814d5f-91e04d 1e-855e-1601439ce0c3?q=bwmeta 1.element.desklight-ab947187-37cb-4949-884d0caa5d619e13;9\&qt= CHIL DREN-STATELESS (09.10.2019).

21 J. Kosuth, Art after Philosophy and After. Collected Writings, 1966-1990, ed. G. Guercio, foreword J.-F. Lyotard, The MIT Press, Cambridge, Massachusetts - London, England 2002, pp. 13-32. 
the concept of art is also extensible, although the absolutist understood basic concept of art is abandoned.

Contrary to the extensionalist and monotonic approaches, in the intensionalist context the logical value of a sentence created with the use of an intensional functor depends not on the logical values of the component sentences, but on their content (intension). ${ }^{22}$ Intensionalism is therefore a simultaneous deprivation of the logical value function of constituent sentences as the sole arguments in determining the logical value of a compound sentence. The intensional approach to the truth of sentence became a basis for the criticism of conceptualism by the contextualism of Jan Świdziński - the Polish artist and theoretician. ${ }^{23}$ Świdziński's introduction the notion of intensionality into the general theory of art is up to the standards of understanding a work of art as tautology or Kosuth's analytic statement. Świdziński compared artifacts not to analytic statements, as the first Kosuth (or statements created with the use of extensional functors whose logical value depends on their value - scope, extension - of the component statements) but to statements containing intensional functors (their logical value depends on the content substituted in place of variables). According to Świdziński, the notion of intensionality, posing problems to logicians, better explained the character of artistic creation than a tautological formula which does not convey any knowledge about reality and makes claims to being true in all the possible worlds. Intensionality of an artistic statement, i.e. the presence of functors in it (e.g. I know, I recognize, I believe, I suppose or I should, etc.) examined by epistemic or deontic logic, indicates its limitation by the pragmatic moment of experience. Świdziński searched for a verifying concept of meaning in art in order to fill the void of conceptualists' arbitrary linguistic behavior. According to Świdziński, tautologism of the first Kosuth was an extreme consequence of the modernist model of art which turned out to be relativist. Świdziński criticized this model for its utopian character. We only have such relativism that we can afford at a particular time, that we can produce, or how far we want to or allow ourselves to differ. That is why Świdziński referenced to the operationalist theory of meaning. Operationalism was originated in 1927 by Percy William Bridgman. Operationalists, mistrustful of the descriptive method of defining a term by simple listing of its features, because it may lead to empty verbalism, demanded subjecting an activity to a set of operations (scientific operations, procedures) thanks to which we claim that a certain property is adequate for the object: be it in physics or social sciences,

22 W. Marciszewski, Logika formalna, op. cit., pp. 67-68, 279, 285, 292-293.

23 J. Świdziński, Art as Contextual Art, Sellem Galerie St. Petri - Archive of Experimental Art, Lund 1976; idem, Art, Society and Self-consciousness, Alberta College of Art Gallery, Calgary - Canada 1979. 
or - as Świdziński wanted - in the theory of art. On the basis of operationalism, Świdziński attempted to overcome the verbalism of conceptualism with Judd's famous nominative definition of art, quoted by Kosuth. Naming itself does not suffice because art as an empty sign acquires or loses meaning - artistic truth or acceptance - only on the ground of concrete social practice, being a function of a way of speaking about reality, produced by a certain community. The term empty sign does not mean nothing or something, but something else. Artistic practice ceases to be identified with creation in a concrete medium and becomes pragmatics of art, which aims at defining what operations need to be performed at a particular moment to gain social acceptance.

\section{The non-monotonic context}

The living thinking ignores the metalogical principle of monotonicity implicitly assumed both by essentialism and anti-essentialism. Of yore, when Władysław Strzemiński visited Witkacy in Zakopane to learn more about his formalist theory of art, the former Formist - pointing to the famous Portrait Company products - was to declare that they are not art, although earlier he painted and recognized portraits as art. Leon Chwistek would interpret this flip-flop of the essentialist, of course, as anti-essentialist. A logical approach to this new situation would be: CACepCNepKNpp. The principle of monotonicity dictates the conclusion that a portrait is an art even when we add a contradictory statement to the original set of premises and conclusions. We can easily prove it, because if the predecessor is false and the successor true, then the implication is true.

This logic of the monotonic context means that the monotonic interpretation of art turns out to be useless in this case. Witkacy - during a conversation with Strzemiński and Julian Przyboś - gave the products of his Portrait Company the different sense than before, so the intension of the word portrait has changed in this different model of preferences. This changed the extensionalist context to intensionalist, and consequently - the monotonic to non-monotonic. ${ }^{24}$ The intensionalist context demonstrates that intuitions inherent in it are convergent with the intuitions of originators of non-monotonic logics, limiting the applicability of meta-logical principle of monotonicity. For example Dov M. Gabbay defined non-monotonic inference as a relation between sets of sentences and sentences fulfilling certain conditions. This is how contextualism

24 See: K. Piotrowski, Estetyka niemonotoniczna. Implikacje sporu konceptualizm vs kontekstualizm, in: K. Wilkoszewska, A. Zeidler-Janiszewska (Eds.), Konteksty sztuki - konteksty estetyki. Perspektywy estetyki, Officyna Wydawnictwo, Łódź 2011, pp. 259-268. 
would define the basic relations in art, i.e. that works of art are expressible in statements built from intensional functors, i.e. their truth is conditioned by the meaning (contents) and not by extension. Gabbay violated, limited (like Świdziński tried to limit conceptualism) the principle of monotonicity, supplanting it with a much weaker condition of cumulativity, which claims that premises are not random, as in Tarski's rule of monotonicity (or Kosuth's conceptualism) but only such which can be inferred from the previously accepted premises. At this early stage of the development of non-monotonic logics, the principle of limited or careful cumulativity was discussed. Then it turned out that in living thinking - where we deal with unexplicited (extramural) premises, with expectations that change in different circumstances, in connection with the dynamic process of reasoning as a component of human contextual experience - that of these three Gabbay's axioms only the reflexivity axiom is beyond doubt. The upshot is that the weakened monotonicity (cumulativity) principle could not be maintained. Therefore, David Makinson - by creating the semantic foundations of this non-monotonic logic by developing the theory of preferential models - proposed a positive definition of non-monotonic logics. He called them logic and defeasible reasonings, that is, such reasoning in which the conclusion once proven does not have to remain valid, because it can be annulled when circumstances change. Makinson writes, that a given relation of consequences will be called non-monotonic, if and only if when it can be, that the proposition $\mathrm{x}$ is a consequence of the set of propositions $\mathrm{A}$, but is not a consequence of its superset $\mathrm{A} \mathrm{v} \mathrm{B.}{ }^{25}$ It is easily noticeable that the pursuit of non-monotonic logics is convergent with intuitions of Świdziński who introduced the notion of art as an empty sign, and not the notion of an open sign, understood as a cumulative set. ${ }^{26}$

Based on the non-monotonic logic one can expose the experiment cited by Fenner: Anita Silvers, in 'Vincent's Story: The Importance of Contextualism for Art Education', ${ }^{27}$ relates an experiment she conducted on a group of pre-secondary-level students. She told them, while showing them a set of slides of works by Van Gogh, an apocryphal story in which Van Gogh is portrayed as a kind of con artist. Silvers reports that the students, who had up to that point been offering positive responses to Van Gogh's work, suddenly began saying negative things. All this point, Silvers revealed her deceit. But, she reports, the students did not go back

25 D. Makinson, Od logiki klasycznej do niemonotonicznej, transl. T. Jarmużek, Wydawnictwo Naukowe Uniwersytetu Mikołaja Kopernika, Toruń 2008, p. 2.

26 See: K. Piotrowski, Świdziński i współcześni. Konteksty 'sztuki jako sztuki kontekstualnej' i estetyka niemonotoniczna, Mazowieckie Centrum Sztuki Współczesnej „Elektrownia”, Radom 2015.

27 A. Silvers, Vincent's Story: The Importance of Contextualism for Art Education, "Journal of Aesthetic Education” 1994, no 3, pp 47-62. 
to their original positive reactions to VG; even though she revealed the falsity of the negative stories about his life, the students had already internalized them, and their observations of his work were now, to some degree, permanently colored by the false stories. ${ }^{28}$ We see that despite the successively attached premises, including démenti, a certain model of preferences formed in students persisted, disturbing the correct course of their reasoning. This unexplicited reference model created a context that limited the possibility of adding new premises to the original set of premises and conclusions. According to Makinson, we all think non-monotonically, i.e. in live, in contextual thinking we ignore the metalogical principle of monotonicity.

\section{The machine-epistemologic context}

Since the end of the 20th century, the non-monotonic logic - i.e. the logic of defeasible reasoning occurring in a situation of uncertainty, where not all premises are given explicitly - has become a component of logic labelled as supra-classical. This logic plays a key role in the modern civilization developing artificial intelligence products. The methodology of science, whose rationality has hitherto been to formulate hypotheses, devise experiments and confront their results with hypotheses in order to draw conclusions and establish the facts, has been modified. With the use of high-performance computing machines, which began to process huge amounts of data, it was possible to reduce the uncertainties that arise when interpreting the results of experiments. But the knowledge did not become certain, because it was obtained with the help of statistics. ${ }^{29}$ Thus, the research process is first limited by a way of compiling data that are not objectively found as in the classic episteme. That is why it is already an artificial construct. Then we need to adopt some rules for modeling this data that will be tested with the help of a statistical method, so that any conclusions can be drawn. However, the question remains: are these conclusions reliable if they were based on a statistical method? Rather they remain grounds for further research, and therefore cannot constitute normative knowledge.

Art theory must also begin to reckon with this type of knowledge generated by the machine-epistemological context, as Gregory Wheeler writes, "Martin Nowak and colleagues have looked at the evolutionary dynamics of language to figure out how the rate of verb regularization depends on the frequency of word

28 D. E. W. Fenner, Art in Context, op. cit., p. 137.

29 G. Wheeler, Machine Epistemology and Big Data, in: L. McIntyre and A. Rosenberg (Eds.), The Routledge Companion to Philosophy of Social Science, Routledge, New York 2017, pp. 321-329, http://gregorywheeler.org/papers/Machine-Epistemology.pdf (09.10.2019). 
usage. This is precisely the sort of claim that not too long ago was forwarded a priori rather than tackled empirically. Jean-Baptise Michel, Nowak, and colleagues have looked at $4 \%$ of all the books ever published, a staggering 5,195,769 digitized books, to explore cultural trends recorded in the English language between 1800 and 2000. Of 'culturomics' they say, We show how this approach can provide insights about fields as diverse as lexicography, the evolution of grammar, collective memory, the adoption of technology, the pursuit of fame, censorship, and historical epidemiology. Culturomics extends the boundaries of rigorous quantitative inquiry to a wide array of new phenomena spanning the social sciences and the humanities." 30

Today art operates to a large extent on the Internet, and the data on it is huge and is constantly growing, undergoing constant transformation. Art data is edited, shared or privatized, updated or simply deleted. The evidentialist truth of art, i.e. the empirical criteria for determining data, no longer come solely from the field of traditional episteme, but are offered as partial data results - as in the Google's browser - subjected to the computational power of artificial intelligence. This process of searching large databases - according to accepted models as in the above-mentioned culturomics - has not been completed. From the point of view of traditional aesthetics, conceived as a part of epistemology, this is an uncomfortable situation. This is because it cannot maintain certainty about its essentialist or even anti-essentialist achievements, which it acquired through monotonic logic. Meanwhile, in machine epistemology, the output data of research is not static and cumulated according to the monotonicity principle, but may change during the study. At the entrance some premises are accepted and conclusions are drawn to be canceled after obtaining other data, which will result in the loss of accepted conclusions and modification past results. Machine epistemology does not limit us to comprehend art as a definite - closed or open - monotonically understood cumulative set in which the original order is inviolable. Our knowledge of art is now to be based on the assumption that uncertainty is no longer undesirable, but - as Wheeler writes - is to be used to generate creative uncertainty. Therefore, the concepts in the machine episteme are to perform an interrogative function, not to impose final solutions.

The context of the answer to the question What is art? thus becomes Unsupervised Learning. The learner with the help of the machine has a huge amount of data, but does not have the definition of art and a control system sending him feedback, as in Supervised Learning, whose theoretical background would be essentialism or anti-essentialism, where the concepts are a priori or 
a posteriori defined. Unsupervised Learning does not have explicited knowledge, i.e. basic, factorial and result (essentialism) or only factorial and result (anti-essentialism) concepts of art. In Unsupervised Learning, we don't know what the resulting answer should look like, because the data does not have to be indexed or context-correlated using the expressions $\tau \dot{\varepsilon} \chi v \eta$, ars, l'art, art, Kunst, sztuka, искусство, نف, 艺 etc. We just need to derive the concept of art from the data available to us, as in clustering, although we do not know the impact of variables which condition our learning process when we spend some time in front of computer. The computer is just an algorithm, but algorithm that takes into account unsupervised learning algorithms in the Internet where the data change during heuresis. Reinforcement Learning combined with a reward, when a learner interacts with the viewed data, recognizes various art games and participates in one of them to obtain a reward whose value can be measured with a tool such as PageRank. Today, this is how art works, as evidenced by various rankings of popularity, influence of artists or critics, citations of theoreticians, magazines, exhibitions or other artistic events that position them every year in the hierarchy as Spotify ranking of artist.

But this euphoria of pragmatism, whose postulate is not to uncover the truth but to create it using uncertainty, evokes the ambivalence of the myth of Epimetheus. This myth was recalled by Plato in the Protagoras dialogue: Once upon a time there were gods only, and no mortal creatures. But when the time came that these also should be created, the gods fashioned them out of earth and fire and various mixtures of both elements in the interior of the earth; and when they were about to bring them into the light of day, they ordered Prometheus and Epimetheus to equip them, and to distribute to them severally their proper qualities. Epimetheus said to Prometheus: 'Let me distribute, and do you inspect.' This was agreed, and Epimetheus made the distribution. There were some to whom he gave strength without swiftness, while he equipped the weaker with swiftness; some he armed, and others he left unarmed; and devised for the latter some other means of preservation, making some large, and having their size as a protection, and others small, whose nature was to fly in the air or burrow in the ground; this was to be their way of escape. Thus did he compensate them with the view of preventing any race from becoming extinct. And when he had provided against their destruction by one another, he contrived also a means of protecting them against the seasons of heaven; clothing them with close hair and thick skins sufficient to defend them against the winter cold and able to resist the summer heat, so that they might have a natural bed of their own when they wanted to rest; also he furnished them with hoofs and hair and hard and callous skins under their feet. Then he gave them varieties of food, - herb of the soil to some, to others fruits of trees, and to others roots, and to some again he gave other animals as food. And some he made to have few young ones, while those who were their prey were very prolific; and in this manner 
the race was preserved. Thus did Epimetheus, who, not being very wise, forgot that he had distributed among the brute animals all the qualities which he had to give, - and when he came to man, who was still unprovided, he was terribly perplexed. Now while he was in this perplexity, Prometheus came to inspect the distribution, and he found that the other animals were suitably furnished, but that man alone was naked and shoeless, and had neither bed nor arms of defence. The appointed hour was approaching when man in his turn was to go forth into the light of day; and Prometheus, not knowing how he could devise his salvation, stole the mechanical arts of Hephaestus and Athene, and fire with them (they could neither have been acquired nor used without fire), and gave them to man. Thus man had the wisdom necessary to the support of life, but political wisdom he had not; for that was in the keeping of Zeus, and the power of Prometheus did not extend to entering into the citadel of heaven, where Zeus dwelt, who moreover had terrible sentinels; but he did enter by stealth into the common workshop of Athene and Hephaestus, in which they used to practice their favourite arts, and carried off Hephaestus' art of working by fire, and also the art of Athene, and gave them to man. And in this way man was supplied with the means of life. But Prometheus is said to have been afterwards prosecuted for theft, owing to the blunder of Epimetheus. ${ }^{31}$

Because of this mistake made by Epimetheus, unspecified human nature in the natural world would fall below specified animal nature. However, the lack of man determination by the attributes given to other species turned out to be an advantage and it was a very successful event with high motivation to human inventiveness. Prometheus - the merciful titan looking ahead - taught us all the arts. As we known, the Promethean progressive semi-essentialism that prevailed until the end of modernism - is problematized today. Even if the lack has appeared in statu nascendi of art, thanks to which man has dominated the natural world, then this time the lack was repeated. A man endowed with titanic power has fallen into technique. This fall was described, among others, by Martin Heidegger, and became a permanent factor of conditio humane in the anthropocene phase. In 1994, Bernard Stiegler distinguished, apart from an organic being and an inorganic one, a third type - an inorganically organized being. Thus, man is not only an inventor or an user, but also a fitter or a serviceman of technician equipment, and therefore he belongs to the resources of technology. Therefore, in the anthropocene, épimètheia and promètheia as two figures of temporalization cannot be separated, just as the separation of tekhne from épistēme has become a problem. ${ }^{32}$

31 Plato, Protagoras, in: The Dialogues of Plato, transl. B. Jowett, etext A. G. Fernandez, p. 1214, https:// webs.ucm.es/info/diciex/gente/agf/plato/The_Dialogues_of_Plato_v0.1.pdf (09.10.2019).

32 B. Stiegler, Technics and Time, 1. The Fault of Epimetheus, transl. R. Beardsworth and G. Collins: Stanford University Press, Stanford California 1998, pp. 16-17, 21. 
In this situation, the question posed in the introduction - Is a conceptualizing of 'art' needed? - gains the different machine-epistemological context at the end of these considerations. This problem assumes a question about the importance of traditional epistemology, where humans - as an organic being - organized various inorganic beings into art as a quasi-organism. Meanwhile, our answer must also take into account the context of machine epistemology, in which art ceases to be a determined concept, but itself as a machine organizes inorganically an organic being, i.e. its knowledge. In the machine epistemology context, of which the non-monotonic logic is a component, the old expressions of art determined by the dispute between essentialism and anti-essentialism together with their monotonic logic no longer have the only binding power.

\section{China's Van Goghs (2016)}

The outlined contexts - from essentialism to machine epistemology show that our matter is complicated and there is no simple answer to it. While the dispute between essentialists and anti-essentialists remains a difficult issue, it does not pose a major existential challenge for the human species. The more so that this dispute is being fought in a more or less liberal aura in order to normalize or intensify human inventiveness and the richness of art (its ubertas aesthetica). However, the machine-epistemological context - generated by the earlier development of episteme - must raise more concern than disputes of absolutists with relativists. This epimetheic fall into technology seems to be more and more a victory of art over human nature. All meanings are now to be redistributed by an inorganically organized being. So this issue implies a question of monstrosity, because the monster is coming to the foreground of the modern way of life through Suzy technological revolution, as Peter Sloterdijk rightly suggested in the discussion with Bernard Stiegler, ${ }^{33}$ and what Jacques Derrida earlier announced in De la grammatologie (1967): L'avenir ne peut s'anticiper que dans la forme du danger absolu; il ne peut s'annoncer que sous l'espčce de la monstruosité. ${ }^{34}$ The question: What is art, and especially what should art be for man? turned into a question: What should man be for art? And this constitutes an important step to the technological monstrosity which, by its very essence, evades all determination. That is why Luciano Floridi has been dealing with the Augmented Intelligence issue for many years, developing the so-called Digital Ethics. Although the death of art was announced by Dadaists, Productivists

33 Welcome to the Anthropocene. Debate with philosophers Peter Sloterdijk and Bernard Stiegler (27. 06. 2016), De Vereeniging, Nijmegen, https://www.youtube.com/watch?v=ETHOqqKluC4 , 18'43 - 19'41 (09.10.2019).

34 J. Derrida, De la grammatologie, Éditions de Minuit, Paris 1997, p. 14. 
or Theo van Doesburg who observed the progress in transforming the natural world into art, nevertheless - as in the catastrophism of Stanisław Ignacy Witkiewicz - the effort to define art was not abandoned. So, what has changed in our episteme that we should give up this aspiration?

Today a man - a contractor, fitter or technician serviceman, becomes something defined by art, not just someone who defines art. Along with globalization, the pressure of inconclusive interpretationism, tourism, proceduralism and consumerism has increased. The most people just need to use technical effects without knowing their spiritual or epistemic premises, as shown by $\mathrm{Yu}$ Haibo and Kiki Tianqi Yu - the authors of the documentary film China's Van Goghs (2016). "Since I know the client in Amsterdam I have a dream to visit the Van Gogh Museum. See his originals and to feel how he felt. I want to get some inspiration from his paintings then my goal will be more clear," the subtitles read. ${ }^{35}$ It is difficult for us to understand what the mass replica manufacturer means. Does he want to deepen the knowledge of the knowing that type or does he simply want to increase the effectiveness of the knowledge of the knowing how type? But why would Zhao Xiaoyong - who has increasingly better Chinese connectivity - bother, despite the objections voiced by his wife, who is in charge of their home budget, since there is no guarantee that his thriving business will provide better art effects than Van Gogh originals? Well, we are dealing not only with another Chinese fake, but with a new product Van Gogh Made in China. This production has an admirable and original added value, since these communist Chinese explore rather than mechanically imitate not just the individual style of the Dutch madman, dreaming of artistic phalanstery, but also Leonardo da Vinci or Claude Monet. They discover - perhaps - a pathetic beauty that resembles the socialist ideals of William Morris or the ideas of impulse and collective formativity from the aesthetics of Luigi Pareyson. Zhao Xiaoyong seems to be fascinated by Van Gogh's personality, but how much is he able to take from the Western understanding of art? Therefore, it is not a matter of plastic rice, or hazards that we cannot tolerate in cooking. However, Zhao seems to explain the purpose of his trip to Amsterdam like his wife and toasting friends: To everyone's business getting better. To big fortune in the year of the Horse. And to have more money soon. ${ }^{36}$ For is it not true that in this way various Western technologies, brands and other financial or spiritual assets are taken over, subjecting them to the communist authorities and exploiting even the western system of fine arts in order to gain new markets and influences in the world? Will China's Van Goghs - after a visit to Amsterdam - understand

35 China's Van Goghs, 6’20 - 6’37, https://www.dailymotion.com/video/x6fcef2 (09.10.2019).

36 Ibidem, 6'59 - 7’05. 
a gap between original and replica, between their strive for money and the mission of Van Gogh, who devoted himself completely to art? It seems that the spiritual needs of art are not completely indifferent to them, although they are subject to the pressure of arhimanic deception in the People's Republic of China. When deeply saddened Zhao realizes it is not easy to become an artist and paint something of his own, then his tipsy interlocutor comforts him: I think artist, painter, painter-worker these are just labels. That's not very important. What's important is how you position yourself. What important is how you fell in your heart, how you do it and how you express yourself. So others would recognise you. ${ }^{37}$ So they can start painting in their own way. All the more that the Chinese market already allows it.

\section{BIBLIOGRAPHY:}

Batteux, Abbé Charles (1989) Les Beaux-Arts réduits à un même principe (1746), ed. by JeanRémy Mantion, Paris: Aux Amateurs de livres.

China's Van Goghs (2016) a film by Yu Haibo and Kiki Tianqi Yu, https://www.dailymotion.com/ video/x6fcef2 (09.10.2019).

Chwistek, Leon (1922) Nowa poezja polska (I. Uwagi metodologiczne), "Nowa Sztuka", no. 2, pp. 11-13, http://bluemountain.princeton.edu/bluemtn/? $\mathrm{a}=\mathrm{d} \& \mathrm{~d}=$ bmtnabm192202-01.2.15\& (09.10.2019).

Chwistek, L. (1933) Zagadnienie metody w estetyce, in: idem, Zagadnienia kultury duchowej w Polsce, Warszawa: Księgarnia Gebetnera i Wolffa, pp. 249-277.

Derrida, Jacques (1997) De la grammatologie, Paris: Éditions de Minuit.

Dessoir, Max (1906) Aesthetik und allgemeine Kunstwissenschaft, Stuttgart: Verlag von Ferdinand Enke, https://archive.org/details/sthetikundallge00dessgoog/page/n7 (09.10.2019).

Eco, Umberto (1989) The Open Work, transl. by Anna Cancogni with an introduction by David Robey, Cambridge, Massachusets: Harvard University Press.

Eco, U. (2008), Estetyka indyjska a estetyka zachodnia (Problemi di estetíca indiana, 1958), in: idem, Sztuka, transl. by Mateusz Salwa, Kraków: Wydawnictwo M, pp. 64-80.

Fenner, E. W. David (2008) Art in Context: Understanding Aesthetic Value, Athens, Ohio: Swallow Press - Ohio University Press.

Fenner, E. W. David (2008) Art in Context: Understanding Aesthetic Value, Athens, Ohio: Swallow Press - Ohio University Press.

37 Ibidem, 40'16-40’41. 
Kiereś, Henryk (1986) Anglosaska estetyka analityczna, in: Antoni B. Stępień, Propedeutyka estetyki, Lublin: Towarzystwo Naukowe Katolickiego Uniwersytetu Lubelskiego, pp. 143-171.

Kiereś, H. (2006) Człowiek i sztuka. Antropologiczne watki problemu sztuki, Lublin: Polskie Towarzystwo Tomasza z Akwinu.

Kosuth, Joseph (2002) Art after Philosophy and After. Collected Writings, 1966-1990, ed. by Gabriele Guercio, foreword by Jean-François Lyotard, Cambridge, Massachusetts - London, England: The MIT Press.

Makinson, David (2008), Od logiki klasycznej do niemonotonicznej, transl. by Tomasz Jarmużek, Toruń: Wydawnictwo Naukowe Uniwersytetu Mikołaja Kopernika.

Marciszewski, Witold (Ed.) (1987) Logika formalna. Zarys encyklopedyczny z zastosowaniem do informatyki i lingwistyki, Warszawa: Państwowe Wydawncitwo Naukowe.

Plato, Protagoras, in: The Dialogues of Plato, transl. by Benjamin Jowett, etexts prepared by Antonio González Fernández, p. 1214, https://webs.ucm.es/info/diciex/gente/ agf/plato/The_Dialogues_of_Plato_v0.1.pdf (09.10.2019).

Piotrowski, Kazimierz (2004) Antyunizm Leona Chwistka - o defensywnej fazie awangardy lat trzydziestych, "Artium Questiones”, no. 15, pp. 30-37.

Piotrowski, K. (2011) Estetyka niemonotoniczna. Implikacje sporu konceptualizm vs kontekstualizm, in: Krystyna Wilkoszewska, Anna Zeidler-Janiszewska (Eds.), Konteksty sztuki - konteksty estetyki. Perspektywy estetyki, Łódź: Officyna Wydawnictwo, pp. 259-268.

Piotrowski, K. (2015) The Linguistic Turn in Conceptualism andAfter, “ArtInquiry”, no. 17, pp. 145166, http://cejsh.icm.edu.pl/cejsh/element/bwmeta1.element.desklight-9a814d5f-91e0-4d1e855 e-1601439ce0c3? q=bwmeta 1.element.desklight-ab $947187-37$ cb-4949-884d0caa5d619e13;9\&qt=CHILDREN-STATELESS (09.10.2019).

Piotrowski, K. (2015) Świdziński i wspótcześni. Konteksty 'sztuki jako sztuki kontekstualnej’ i estetyka niemonotoniczna, Radom: Mazowieckie Centrum Sztuki Współczesnej “Elektrownia”.

Ryle, Gilbert (1946) Knowing How and Knowing That, "Proceedings of the Aristotelian Society", vol. 46 (1945-1946), pp. 1-16, https://plato.stanford.edu/entries/ryle/ (09.10.2019).

Silvers, Anita (1994) Vncent's Story: The Importance of Contextualism for Art Education, "Journal of Aesthetic Education”, no. 3, pp 47-62.

Stiegler, Bernard (1998) Technics and Time, 1. The Fault of Epimetheus, transl. by Richard Beardsworth and George Collins, Stanford California: Stanford University Press.

Świdziński, Jan (1976) Art as Contextual Art, Lund: Sellem Galerie St. Petri - Archive of Experimental Art.

Świdziński, J. (1979) Art, Society and Self-consciousness, Calgary - Canada: Alberta College of Art Gallery. 
Tatarkiewicz, Władysław (1988) Dzieje sześciu pojęć. Sztuka, piękno, forma, twórczość, odtwórczość, przeżycie estetyczne, Warszawa: Państwowe Wydawnictwo Naukowe.

Utitz, Emil (1914) Grundlegung des allgemeinen Kunstwissenschaft, Stuttgart: Verlag von Ferdinand Enke, https://archive.org/details/grundlegungdera00utitgoog/page/n7 (09.10.2019).

Welcome to the Anthropocene. Debate with philosophers Peter Sloterdijk and Bernard Stiegler (27. 06. 2016), De Vereeniging, Nijmegen, https://www.youtube.com/watch?v=ETHOqqKluC4 (09.10.2019).

Wheeler, Gregory (2017) Machine Epistemology and Big Data, in Lee McIntyre and Alex Rosenberg (Eds.), The Routledge Companion to Philosophy of Social Science, New York: Routledge, pp. 321-329, http://gregorywheeler.org/papers/Machine-Epistemology.pdf (09.10.2019).

\section{KILKA KONTEKSTÓW PYTANIA O SZTUKĘ Od esencjalizmu do maszynowej epistemologii (streszczenie)}

Ponieważ znam klienta w Amsterdamie, marzę, by odwiedzić Muzeum Van Gogha. Zobaczyć jego oryginaty i poczuć to, co on czut. Chcę inspirować się jego obrazami, bo wtedy mój cel będzie bardziej wyraźny - czytamy napisy w filmie China's Van Goghs (2016). Trudno nam zrozumieć znaczenie tej wypowiedzi producenta masowych replik. Czy jego pragnieniem jest pogłębienie wiedzy typu knowing that czy chce tylko podnieść efektywność posiadanej już wiedzy typu knowing how? Ale po cóż Zhao Xiaoyong - dysponujący coraz lepszą chińską connectivity - miałby trudzić się, skoro nie ma gwarancji, że jego świetnie prosperujący biznes dostarczy doskonalsze efekty sztuki niż oryginały Van Gogha? Czy istnieją inne konteksty - jak na przykład uczenie bez nadzoru w których możemy inaczej spojrzeć na słynne rozróżnienie Gilberta Ryle’a i uprzywilejowaną pozycję dobrze ugruntowanej wiedzy?

Słowa kluczowe: sztuka, esencjalizm, ekstensjonalizm, intensjonalizm, logika niemonotoniczna, maszynowa epistemologia, uczenie się bez nadzoru.

Kazimierz Piotrowski - PhD, art historian, critic, curator and philosopher of art. Studied history of art and philosophy at the Catholic University in Lublin. Obtained his PhD at the Institute of Art of the Polish Academy of Sciences and Letters (PAN) in 2000. He was working at the National Museum in Warsaw (1990 - 2003) and as a curator at the Xawery Dunikowski Museum of Sculpture in 2001. Since 2004 a lecturer in philosophy and art history at the Academy of Fine Arts and Design in Łódź. Published among others the books Krzysztof Zarębski. Erotematy stabnacego Erosa. Przyczynek do dziejów sztuki performance w Polsce i Stanach Zjednoczonych po 1968 roku [Krzysztof Zarębski. The Erothemes of the Weakening Eros. A Contribution to the History of Performance Art in Poland and the United States after 1968] (2009), Świdziński i wspótcześni. Konteksty 'sztuki jako sztuki kontekstualnej' i estetyka niemonotoniczna [Świdziński and His Contemporaries. The Contexts of the 'Art as Contextual Art' and the Non-monotonic Aesthetics] (2015). 